\title{
COMMENTS
}

\section{BROKERAGE AND THE BROCH CASE: CONFLICT AND COMPRO- MISE BETWEEN SECTIONS 2(a) AND 2(c) OF THE ROBINSON-PATMAN ACT}

Section 2(c) of the Clayton Act, as amended by the Robinson-Patman Act, makes it unlawful for any person to grant brokerage, or any allowance or discount in lieu thereof, to the other party to a transaction. ${ }^{1}$ The brokerage provision has been branded by its critics as the most ambiguous and faultilydrafted section of the Robinson-Patman Act, 2 yet due to the FTC's early preoccupation with enforcement of the clause, it has been regarded as the only section as to which no important question of interpretation remained unsettled. 3 The status quo was altered when the Seventh Circuit in Henry Broch \& Co. v. FTC 4 held that neither the language nor the legislative history of section 2(c) indicated that a seller's broker was covered by that section. Granting certiorari for the first time in a case interpreting section 2(c), 5 the Supreme Court reversed the lower court in a five to four decision. ${ }^{6}$

The language of the majority opinion and the strength of the dissent have reopened old problems and created new ones. The problems arise when the commission of the seller's broker is eliminated or diminished with the savings passed on to the buyer in a lower price. The situation compels re-examination of the relation between the absolutely prohibitive brokerage clause and sec-

1 Section 2(c) provides: "It shall be unlawful for any person engaged in commerce, in the course of such commerce, to pay or grant, or to receive or accept, anything of value as a commission, brokerage, or other compensation, or any allowance of discount in lieu thereof, except for services rendered in connection with the sale or purchase of goods, wares or merchandise, either to the other party to such transaction or to an agent, representative, or other intermediary therein where such intermediary is acting in fact for or in behalf, or is subject to the direct or indirect control, of any party to such transaction other than the person by whom such compensation is so granted or paid." 38 Stat. 730 (1914), as amended, 49 Stat. 1527 (1936), 15 U.S.C. §13(c) (1958).

2 Austin, Price Discrimination and Related Problems Under the Robinson-PatMaN ACT 100-09 (rev. ed. 1953); Austern, Section 2(c), CCH Robinson-Patman Act SYMPOSIUM 37 (1946).

3 Austin, op. cit. supra note 2, at 100; Edwards, The Price Discrimination Law 92 (1959) (hereinafter cited as EDwards); Note, 100 U. PA. L. Rev. 107, 109 (1951).

4261 F.2d 725 (7th Cir. 1958).

5 As a matter of record, until Broch, certiorari in a 2(c) violation had not been sought since Southgate Brokerage Co. v. FTC, 150 F.2d 607 (4th Cir. 1945), cert. denied, 326 U.S. 774 (1945).

6 FTC y. Henry Broch \& Co., 363 U.S. 166 (1960). Mr. Justice Douglas delivered the opinion of the Court. Mr. Justice Whittaker wrote the dissent, in which he was joined by Justices Frankfurter, Harlan, and Stewart. Id. at 177. 
tion 2(a), which provides that nothing shall prevent price differentials "which make only due allowance for differences in the cost of manufacture, sale, or delivery resulting from the differing methods ... in which such commodities are ... sold or delivered. ..."7

\section{BACKGROUND, INTERPRETATION, AND THE CRITICS}

The background and legislative history of the Robinson-Patman Act generally, ${ }^{8}$ and the brokerage provision in particular, ${ }^{9}$ are so extensively treated elsewhere that no reiteration is warranted. Suffice it to say that 2(a) has prohibited direct and indirect discrimination in price, with certain affirmative defenses permitted by the proviso. Section 2(c), on the other hand, was designed to prohibit absolutely discrimination concealed in equal prices, but found by Congress to be commonly practiced for the purpose or result of giving a competitive advantage to large buyers. Whereas 2(a) was directed at the seller, 2(c) by its terms covered all the parties to the transaction.

The variety of sales situations to which the brokerage section may be applicable is manifold. To find a market, manufacturers, according to their size and needs, employ several methods. The integrated concern with its own selling department deals directly with prospective customers. The independent seller's broker, like Broch \& Co., who represents more than one principal, is frequently used. Suppliers may deal directly in some transactions at the same time they employ brokers in others. Occasionally the independent broker uses subbrokers when the sale is in a distant or unfamiliar territory. The broker sometimes buys goods for resale on his own account. On the other side, the buyer either maintains his own buying department and field agents or employs an independent broker on a commission basis. The typical transaction at which section 2(c) was aimed was the creation of a "dummy broker" by a large buyer, who pressed the seller into paying to the dummy a

7 Section 2(a) of the Robinson-Patman Act, 49 Stat. 1527 (1936), 15 U.S.C. §13(a) (1958), provides, in pertinent part: "It shall be unlawful for any person engaged in commerce ... to discriminate in price between different purchasers of commodities of like grade and quality ... where the effect of such discrimination may be substantially to lessen competition or tend to create a monopoly . . . or prevent competition with any person who either grants or knowingly receives the benefit of such discrimination, or with customers of either of them: Provided, that nothing ... shall prevent differentials which make only due allowance for differences in the cost of manufacture, sale, or delivery resulting from the differing methods or quantities in which such commodities are ... sold or delivered."

8 The best recent exposition is found in EDwards 1-53. Rowe, The Evolution of the Robinson-Patman Act: A Twenty-Year Perspective, 57 Colum. L. Rev. 1059, 1067-74 (1957), contains a briefer treatment.

9 Austin, op. cit. supra note 2, at 100-09; EDWARDs 92-130; Austern, supra note 2; Chadwell, Analyses of 2(c), ChrCago Bar Symposium on RoBInson-Patman Act (1947); Oppenheim, Administration of the Brokerage Provision of the Robinson-Patman Act, 8 GEO. WASH. L. REV. 511 (1940). 
commission which the latter subsequently passed on to the buyer, thus resulting in a lower ultimate price.10

During the first ten years of the enforcement of the statute, nearly half the FTC cease-and-desist orders were under the brokerage provision. ${ }^{11}$ The courts were quick to resolve an important ambiguity-the "services rendered" exception. The exception was effectively read out of the act 12 by a series of courts of appeals' opinions which rejected the assertion that a brokerage payment to a buyer or his agent was justified by services rendered the seller. Thus the allegation of the buyer was discarded in cases involving the field agents of a large chain store purchaser, ${ }^{13}$ professional "brokers" when purchasing for their own account, 14 sales through a broker to a customer controlled by the same individuals as those in the brokerage house, 15 payments to a marketinformation service on purchases made by its customers, 16 and payments to a co-operative association on purchases by its members. 17 By determining that no middleman remotely affiliated with the buyer could render the appropriate "services" in the exception, the courts left only the independent broker to conduct a "legitimate" distributive function under the interpretation of section 2(c).

The independent brokers, like Henry Broch \& Co. in the instant case, however, were restrained by a series of Commission orders issued in the period from 1940 to 1946 from "splitting" their commission with purchasers who bought through them directly instead of through subbrokers. 18 In the majority of these situations, the broker usually received brokerage for goods bought for resale on his own account as well, and in both instances a violation of sec-

10 S. Rer. No. 1502, 74th Cong., 2d Sess. 7 (1930).

11 EDWARDS 69.

12 Report of the Attorney General's National Committee to StUdy the ANTItrust LAws 188 (1955) (hereinafter cited as ATTORNEY GENERAL's REPORT); AUSTIN, op. cit. supra note 2, at 105.

13 Great Atl. \& Pac. Tea Co. v. FTC, 106 F.2d 667 (3rd Cir. 1939), cert. denied, 308 U.S. 625 (1940).

${ }^{14}$ Southgate Brokerage Co. v. FTC, 150 F.2d 607 (4th Cir. 1945), cert. denied, 326 U.S. 774 (1945).

15 Webb-Crawford Co. v. FTC, 109 F.2d 268 (5th Cir. 1940), cert. denied, 310 U.S. 638 (1940).

16 Biddle Purchasing Co. v. FTC, 96 F.2d 687 (2d Cir. 1938), cert. denied, 305 U.S. 634 (1938); Oliver Bros., Inc. v. FTC, 102 F.2d 763 (4th Cir. 1939).

${ }^{17}$ Quality Bakers of America v. FTC, 114 F.2d 393 (1st Cir. 1940).

18 The brokers subject to these FTC orders were agents of sellers in the canned fruit and vegetable field, working on a $4 \%$ brokerage fee. When sales were made through local brokers, $50 \%$ of the fee was legitimately passed to the sub-agents. But in sales made directly, without the use of subbrokers, $50 \%$ of the fee was also passed to these purchasers. The latter practice was held in violation of section 2(c). E.g., W. E. Robinson \& Co., 32 F.T.C. 370 (1941); Albert W. Sisk \& Son, 31 F.T.C. 1543 (1940); C. F. Unruh Brokerage Co., 31 F.T.C. 1557 (1940); C. G. Reaburn \& Co., 31 F.T.C. 1565 (1940), 
tion 2(c) was found. In Custom House Packing Corp.,19 a broker having no connection with the buyers and not buying for resale was prevented from passing on any part of his brokerage fee to the subbrokers who bought on their own account and then resold the goods. ${ }^{20}$ None of these orders was reviewed in the federal courts, ${ }^{21}$ and the commentators assumed without question that such a "split" of commission was illegal under the section.22

Of more immediate importance to the operation of sections 2(c) and 2(a) was the determination that the brokerage provision was wholly independent of any other section of the Robinson-Patman Act. In an early case, an attempt to justify "brokerage" on the ground that cost savings accrued when a buyer dealt directly with the seller was unsuccessful: the Third Circuit held in the $A \& P$ case $^{23}$ that the act expressed "an absolute prohibition of the payment of brokerage or compensation in lieu thereof to the buyer upon the buyer's own purchases" and rejected the assertion that the allowance A \& $P$ received reflected the seller's saving of brokerage expense. 24 Thus construed, the brokerage clause established a standard of illegality entirely independent of the other statutory provisions, so that the competitive injury requirement in a price discrimination charge and the several defenses available under section 2(a) and 2(b) were irrelevant in an action brought under section 2(c).

Because the specified payments were made unlawful without reference to their effect on competition or their justification by cost differences, proceedings by the Commission have been as frequent as they have been simple.25 The ease of enforcing the section as well as the acquiescence of defendants is

1943 F.T.C. 164 (1946).

${ }^{20}$ After retaining part of its commission, the broker here paid over the remainder to the buying brokers either by (1) deducting commissions from the invoice price of food products purchased, (2) selling to such buyers at a net price reflecting such amount, or (3) remitting such amount by check after the buyer had accepted and honored a draft for the purchase price. Id. at 167. For a revealing post-history of the case see EDWARDs 145-56.

${ }^{21}$ There was, however, dictum in the Fourth Circuit opinion in Oliver Bros., Inc. v. FTC, 102 F.2d 763, 770 (1939): "No one would contend that, without violating this section, a broker representing the seller could give his commission to the buyer...."

22 Austin, op. cit. supra note 2, at 108; Edwards 104, 106; Patman, The RobinsonPatman Act 108 (1938); Oppenheim, supra note 9, at 544; Rowe, How to Comply with Sections 2(c)-(f), 1957 CCH ANITrRust LAW Symposium 124, 127 (1957). Interestingly enough, Rowe, who was attorney for the respondent Broch before the Supreme Court, asserted the proposition as accepted law in his article, citing the Commission report of Broch as authority.

23 Great Atl. \& Pac. Tea Co. v. FTC, 106 F.2d 667 (3rd Cir. 1939).

$24 \mathrm{Id}$. at 673-74. To the same effect are Biddle Purchasing Co. v. FTC, 96 F.2d 687 (2d Cir. 1938) (brokerage section should not be construed in the light of the price discrimination section); Webb-Crawford Co. v. FTC, 109 F.2d 268 (5th Cir. 1940) (effect on competition need not be considered); and Southgate Brokerage Co. v. FTC, 150 F.2d 607, 609 (4th Cir. 1945) ("price discrimination . . . is not necessary to a violation of Section 2(c)").

25 It has been suggested that factors such as short and inexpensive investigations, Commission incentive to institute brokerage cases in order to provide an impressive statistical total, as well as the zealous interest of the organized food brokers in bringing violations to 
vividly shown in the extraordinarily high percentage of admission answers, stipulations of facts, and consent orders. ${ }^{26}$ The only apparent area of conflict remaining, albeit important, was due to the Commission's ambivalence in regard to price concessions to direct buyers made by sellers who sold otherwise through brokers. ${ }^{27}$ Instead of contention and conflict in the courts and before the Commission, opposition to the brokerage provision was now reserved to the critics.

That the Robinson-Patman Act in general is inconsistent with the Sherman and Clayton Acts is frequently asserted.28 Section 2(c) itself has been severely criticized because its absolute prohibition, unavailability of the cost-justification defense, and lack of competitive injury requirement foster price discrimination against certain buyers who do not benefit from actual costs savings accruing to their sellers. 29 The most telling criticism, however, properly exposes the disparity in statutory consequences that attach to economically equivalent business practices. ${ }^{30}$ For if price concessions and payments that ordinarily would be subject to section 2(a) are instead found to be allowances in lieu of brokerage, different rules are automatically applied to what are otherwise identical practices. Form instead of substance thus governs a businessman's conduct, with the anomalous result that symposia on "How to Comply with the Robinson-Patman Act" contain suggestions on how to avoid violation of section 2(c) by doing the same thing in terms of the safer section 2(a). 31

FTC attention have played their part in the frequency of brokerage orders. EDWARDs 71. On the active interest of the food brokers see further, Edwards, Twenty Years of the Robinson-Patman Act, 29 J. Bus. U. CHI. 149, 151-52 (1956).

26 Edwards, Appendix A, Table 1, 661-71.

27 The Broch case, as shown in the text accompanying notes 68-78 infra, brings this problem directly to the fore. Except for the $A \& P$ case, $106 \mathrm{~F} .2 \mathrm{~d} 667$ ( $3 \mathrm{rd} \mathrm{Cir.} \mathrm{1939),} \mathrm{the}$ issue previously had remained in the hands of the Commission.

${ }^{28}$ E.g., Adelman, Effective Competition and the Antitrust Laws, 61 HARv. L. Rev. 1289, $1327-50$ (1948).

29 "It [the brokerage section] is a hard rigid piece of legislation, startling in its implication. So far as intermediary merchandising functions of the brokerage type are concerned, the Act attempts to deprive integrated concerns of the value of their assets used for these purposes. Perhaps it does so on the theory that costs are only bookkeeping transactions but it is not willing to let the matter be put to the proof. The brokerage section, of course, hides under traditional concepts opposed to fraud and double dealing. It is another example of the disease of duplicity with which the Act is inflicted." Levi, The Robinson-Patman Act-Is it in the Public Interest?, 1952 ABA Section of ANTITRUST LAW 60, 69 (1952); see Oppenheim, Federal Antitrust Legislation: Guideposts to a Revised National Antitrust Policy, 50 MICH. L. REv. 1139, 1206-07 (1952).

30 AtTORNEY GENERAL's RePORT 191. See the persuasive examples used in EDwARDS $100-03$.

31 E.g., Rowe, How to Comply with Sections 2(c)-(f), 1957 CCH ANTrTRUST LAW SYMPosium 124 (1957). For an attempted avoidance of section 2(c) that failed, see the instructions of A \& P to its "buying agents" in Great Atl. \& Pac. Tea Co, v. FTC, 106 F.2d 667, 670-71 (3rd Cir. 1939). EDWARDS 102, 108-13. 
Into the more than rarefied atmosphere of Robinson-Patman moved the Supreme Court, bold at first, then cautious in its economics. ${ }^{32}$ In 1951 the Court, for the first time, recognized the inconsistency of the Robinson-Patman Act with the previous antitrust acts. ${ }^{33}$ This was followed by Mr. Justice Frankfurter's now famous assertion in the Automatic Canteen case that "it is our duty to reconcile such interpretation [of the Robinson-Patman Act], except where Congress has told us not to, with the broader antitrust policies that have been laid down by Congress." 34 In spite of the so-called "new era in competitive pricing" and the Attorney General's National Committee Report which endorsed the Supreme Court's "resolution of every statutory doubt in favor of the Sherman Act's basic antitrust directives," 35 the Court in 1959 adopted the highly criticized per se approach to sustain a charge that section 2(e) had been violated. 36 In rejecting the argument that the cost-justification defense was available under section 2(e), the Court refused to go beyond the statutory language to discuss economic problems relative to Robinson-Patman, stating not only that it was "not in a position to review the economic wisdom of Congress," but also that it "cannot say that the legislative decision to treat price and other discriminations differently is without a rational basis." 37

Confusion and inconsistency were thus not prevalent within the self-contained workings of the brokerage provision, with its simple test of illegality and absolute prohibition. For the first time since 1952, however, review was sought in a brokerage case involving a novel and dramatic use of the clause

32 For a documentation of what the author deemed "Radical Expansion in the Forties' by the Commission and to some extent the courts, to "Retreat and Vacillation in the Fifties," see Rowe, supra note 8, at 1076-85.

${ }^{33}$ In reversing the Federal Trade Commission's position that the defense of meeting competition was only procedural in the face of injury from price discrimination, the Court asserted that "Congress did not seek by the Robinson-Patman Act either to abolish competition or so radically curtail it that a seller would have no substantial right of self-defense against a price raid by a competitor," adding that in view of its holding, there was no need to "reconcile in its entirety, the economic theory which underlies the Robinson-Patman Act with that of the Sherman and Clayton Acts." Standard Oil Co. v. FTC, 340 U.S. 231, 249 (1951).

34 Automatic Canteen Co. v. FTC, 346 U.S. 61, 74 (1953). The Supreme Court's decision interpreted section 2(f) of the act as placing upon the Commission the burden of compiling evidence to show the buyer's knowledge of the illegality of the prices he received.

35 Attorney General's Report 131.

36 FTC v. Simplicity Pattern Co., 360 U.S. 55 (1959). Section 2(e) prohibits sellers from discriminating against one purchaser for resale in favor of another by furnishing sales, services or facilities upon terms not accorded all purchasers on "proportionally equal terms." 49 Stat. 1527 (1936), 15 U.S.C. \$13(e) (1958).

37360 U.S. at 67-68. As regards section 2(c), the Court stated that while section 2(a) is hedged with qualifications, "subsections (c), (d), and (e), on the other hand, unqualifiedly make unlawful certain business practices other than price discriminations." Id. at 65 . See note 52 infra for a discussion of how the Broch case relates to the Standard Oil, Automatic Canteen and Simplicity Pattern decisions. 
by the Federal Trade Commission. Whether the subsequent resolution of the issues involved "facilitates manipulation and fosters confusion" 38 is the question raised by Broch.

\section{The Case-Facts, Litigation, and Decision}

Henry Broch \& Co. is a Chicago brokerage partnership acting as a seller's agent for some twenty-five principals. Among these principals was Canada Foods, Ltd., a Canadian processor of apple concentrate and similar products. Canada Foods was also represented in the United States by other brokerage firms. Broch's commission on sales for Canada Foods was established at five percent ${ }^{39}$ during the negotiations in question. The manufacturer in October of 1954 established a price of $\$ 1.30$ per gallon on its apple concentrate and authorized its brokers to negotiate sales at that price.

The J. M. Smucker Co., a buyer, first negotiated with another of Canada Foods' brokers, Tenser \& Phipps. Smucker wanted a price lower than $\$ 1.30$, but Canada Foods, so notified by Phipps, would not agree. Smucker finally offered to purchase 500 drums at $\$ 1.25$ per gallon, Phipps wiring the offer to his principal. Canada Foods' manager subsequently telephoned Phipps, taking the position that the only way the price could be lowered would be through a reduction in brokerage. Phipps relayed the information to Smucker, explaining that the order could not be confirmed since Phipps was afraid this would constitute a violation of the Robinson-Patman Act. 40

Just prior to this last communication, Broch contacted Smucker in an effort to sell the apple concentrate on behalf of the same supplier. The buyer was still holding to $\$ 1.25$, and when Broch notified the seller, he was also advised that the sale could be made only if brokerage was cut from five percent to three percent. Broch consented and the sale was consummated at the lower price and for that brokerage. Broch continued to collect a five percent fee on other sales of Canada Foods' goods, but subsequent sales to Smucker through Broch were at the reduced brokerage and selling price. 41

The Commission charged Broch 42 with violating section 2(c) and after a

38 ATTORNEY GENERAL'S REPORT 191

39 Broch unsuccessfully contested this finding of fact, asserting that the percent of commissions was not fixed. Record, p. 169. That fluctuating fees were the customary usage in the trade was directly controverted by the rival broker. Record, p. 40-41.

40 Record, pp. 43-44, 122.

41 In an arithmetic analysis, the Federal Trade Commission's Brief showed that Broch and the seller participated equally in the price concession. Brief for the FTC, p. 7. Such "arithmetically commensurate" proof in brokerage cases may be of more than passing importance in view of the Commission's decision in Main Fish Co., 53 F.T.C.88 (1956). See text accompanying note 73 infra.

${ }^{42}$ The seller, a Canadian corporation, was not necessarily exempt from the RobinsonPatman Act, and the buyer was clearly within the Commission's jurisdiction. For a suggestion that FTC selection of respondents appears to be based in part on administrative convenience, see EDWARDS 104-05. 
hearing issued a cease-and-desist order. 43 The Commission found that section 2(c) encompassed sellers' brokers and covered grants or allowances made directly as well as indirectly. It further found that the price reductions were commensurate with the pattern of brokerage involved. The Seventh Circuit reversed ${ }^{44}$ on the basis that neither the language nor the legislative history of section 2(c) applied to a seller's broker. 45 Two policy arguments were then advanced. First, the Commission was found to have interested itself in a private grievance between rival brokers, hence the public interest was not being served. 46 Secondly, in an attempt by the court to construe the brokerage provision in pari materia with antitrust policy, it was averred that to interpret the section as the FTC desired would promote price rigidity and uniformity by rendering brokerage commissions immune from reduction when the seller was negotiating a sale. 47

When the Supreme Court reversed, 48 the only agreement between the majority and minority opinions was that the phrase "any person" in the section included a truly independent seller's broker. The crucial question was whether this particular type of transaction was covered by the section. Relying on the language of the statute, the evil it aimed at, and legislative history, the Court found "no difference in economic effect between the seller's broker

43 Henry Broch \& Co., 54 F.T.C. 673 (1957). In pertinent part, the order required Broch to cease and desist from "paying ... Smucker ... any allowance or discount in lieu of brokerage or any part or percentage thereof, by selling . . . to such buyer at prices reflecting a reduction from the prices at which sales of such foods are currently being effected by respondents for Canada Foods, Ltd. or any other seller principal . . . where such reduction in price is accompanied by a reduction in the regular rate of commission . . ." Id. at 694 (emphasis added).

44261 F.2d 725 (7th Cir. 1958).

45 The court of appeals distinguished the leading brokerage cases reviewed by the federal courts on the ground that they all involved buyers' agents. Id. at 728.

46 See Webb-Crawford v. FTC, 109 F.2d 268, 269 (5th Cir. (1940), cert. denied, 310 U.S. 638 (1940), in which the court stated that "the Trade Commission is not to enter on any enquiry about ... whether a proceeding would be in the public interest. Its duty is to enforce the prohibition."

In one case, the total brokerage involved amounted to $\$ 34.76$. The hearing examiner rejected the argument that no order was appropriate as to so small a matter, holding: "It is the character of the act charged and admitted which the law denounces, not the extent thereof, be it small or great. [Rocky Mountain Wholesale Co., No. 6230 (June 6, 1956).]" EDWARDS 101 n. 27.

47 "Obviously an important element in the cost of food distribution is the commission paid by sellers to their brokers. If a seller is to be forbidden to meet competition by reducing an item in its cost of distribution, then to that extent his costs are frozen without regard for the welfare of the public which must ultimately defray the resultant costs of distribution." 261 F.2d at 729.

For a case note on the Seventh Circuit opinion, focusing on the policy aspect of that decision, see 47 CALIF. L. REv. 961 (1959). Two other case notes on the lower court decision are found in 57 Mich. L. Rev. 926 (1959); 27 GEO. Wash. L. Rev. 758 (1959).

48363 U.S. 166 (1960). 
splitting his brokerage commission with the buyer and his yielding part of the brokerage to the seller to be passed on to the buyer in the form of a lower price." 49 According to the dissenters, the brokerage provision was not framed to affect "legitimately negotiated rates of commission for brokers' services." 50 No payment or allowance was involved; instead the validity of the lower price obtained by Smucker was meant to be determined solely under section 2(a).

Whether one prefers the majority or minority view may well depend on his angle of vision. If the entire transaction is looked at in terms of the buyer's reception of a lower price, it cannot be denied that the $\$ 1.25$ sale would have been impossible unless Broch agreed to eliminate part of his commission. An arbitrary reduction in price and brokerage was made in order to obtain a particular sale. From this viewpoint it is difficult to see any difference between the buyer forcing the seller to pay him brokerage and the buyer forcing the broker to pass up part of his brokerage in order to achieve the desired price. But if the viewer's slant is directed away from what the buyer paid and is focused instead on the negotiation between broker and supplier, some validity may be seen in Mr. Justice Whittaker's dissent. For if Smucker dealt with Canada Foods through a broker already charging a three percent commission, no violation on the broker's part could have occurred if the seller dropped his price for that transaction to $\$ 1.25$. If the "services rendered" exception means anything at all,51 it would have to mean that legitimately negotiated commission rates are not encompassed within section 2(c). The direct result of prohibiting a seller from passing on a "true savings" in the distributive process any time a broker is present is to promote price rigidity by establishing a floor to brokerage commissions. 52

To determine whether the brokerage provision was applied correctly, however, does not appear as important as exploring the future impact of the

49 Id. at $174-75$.

50 Id. at 182.

${ }^{51}$ See the discussion of the "services rendered" exception in the text at notes 12-17 supra.

52 This argument of the minority has the familiar ring of Mr. Justice Frankfurter's "reconciliation of Robinson-Patman with the broader antitrust policies" statement in the Automatic Canteen case. See his language in that case, especially 346 U.S. at 63, 74. The majority of the Court as aligned in Broch (Justices Douglas, Black, Warren, Brennan and Clark) appear more disposed to protect the Robinson-Patman Act from what they consider any serious "loophole." 363 U.S. at 177. This was the approach of the majority minus Mr. Justice Clark in their dissent in the second Standard Oil case, where Mr. Justice Douglas stated, "The Court today cripples the enforcement of the Robinson-Patman Act ... in an important area." FTC v. Standard Oil Co., 355 U.S. 396, 404-05 (1958). Mr. Justice Clark, who left the Standard Oil majority to form a different block in Broch, wrote the opinion for the Court in the Simplicity Pattern case (supra note 36) which upheld the per se thrust of section 2(e). It is interesting to note that Frederick Rowe, who once clerked for Mr. Justice Clark, was attorney for Henry Broch \& Co. as well as for Standard Oil. 
Court's opinion, which is fraught with qualifying language and has effectively rendered section 2(c) internally inconsistent. 53 The Court attempted to limit the scope of its holding to an independent broker's allowance of reduced brokerage to obtain a "particular" order. The Court went on to assert that this does not mean "that every reduction in price, coupled with a reduction in brokerage, automatically compels the conclusion that an allowance in lieu' of brokerage has been granted." 54 Instead, the "savings" in brokerage here were passed on to a "single buyer who was in no way shown to have deserved favored treatment." 55 As the dissent cogently pointed out, the Court has thus left the door open for cases where a reduction in price based on a saving in sellers' brokerage costs may be legally justified. The statute by its terms is absolute and applies to all such cases or to none. To decide otherwise introduces the standards and defenses implicit in section 2(a), thereby weakening the heretofore per se thrust of section $2(\mathrm{c}) .56$

\section{The Problem Areas}

In order to enter safe contracts, buyers, sellers, and brokers must assess the probable effect of the Court's troublesome language. The Commission and the courts must also determine what interpretation should be given the Court's stress of the word "discriminatory" 57 and the purpose of the price reduction. ${ }^{58}$ It may be, as the dissent declared, that the Court has somehow fused section 2(a) with section 2(c). Until the meaning of the implied new standards for determining a violation is clarified, protracted litigation may be expected.

In Broch the seller's commitment to a pre-arranged commission of five percent was an accepted finding of fact. In another case, however, evidence might clearly establish that the amount of commission was left to be negotiated on each sale. In that case, it is not clear whether Broch would apply.59 The Court was not conclusive on this question, but instead suggested as an example that no violation would have occurred had the respondent agreed to accept a three percent commission on "all sales to all buyers." 60 But the brokerage

53 This does not mean that for subsequent application of the section, or until congressional clarification, the majority rationale in Broch may not turn out to be an effective compromise. See textual suggestion accompanying notes 87-90 infra.

54363 U.S. at 175.

56 See $i d$. at $188-89$.

Ss $\mathrm{Id}$. at $177 \mathrm{n} .19$.

57 Id. at 174, 176.

58 "[T] $]$ he reduction in brokerage was made to obtain this particular order and this order only and therefore was clearly discriminatory." Id. at 176.

59 The dissent clearly indicates that section 2 (c) would not be violated in such a situation. Id. at 183.

$60 \mathrm{Id}$. at 176. 
agreement between seller and broker might provide for a negotiation of commission on large orders over a specified amount. ${ }^{1}$ Or the independent broker might agree to a lower rate in sales to four or five customers, but not to all customers. Presumably the Court's stress of a "particular buyer" and "to obtain a particular order" might well include such situations. Problems of proof and the allocation of the proper burden, however, have not been so crucial in the prior administration of the brokerage provision.

Section 2(c) applies to the buyer and seller as well as to the intermediary. In Broch it was conceded that the buyer did not know that part of the reduction was a result of the broker's willingness to forego part of its customary brokerage. This fact, as the Court recognized, was immaterial to the charge against the broker. But the Court went on to say that the buyer's intent "might be relevant were he charged with receiving an allowance in violation of section 2(c)."62 This suggestion does not square with the previous understanding of the provision and may be misleading. It is section 2(f), not section 2(c), which makes it unlawful for the buyer to "knowingly" induce or receive a prohibited discrimination in price. 63 In a case against a seller, for example, the seller was ordered to cease paying brokerage to a brokerage enterprise on sales to a wholesale grocery concern, the stock of which grocery was in the hands of the brokers. The complaint was issued under 2(c) against the seller alone, even though it was found that it had no knowledge of the connection between the broker and wholesaler. ${ }^{64}$ In the Broch situation it is difficult to see how the Court could avoid finding the buyer in violation once a discount in lieu of brokerage was established, for the language of the statute applies uniformly to all parties. 65

If this analysis is correct, Broch may have serious economic consequences on the buyer's method of dealing. For if the buyer may be held in violation of the section without knowledge that the seller and broker secretly altered a prearranged fee, the buyer might refuse to deal with a manufacturer who uses brokers. Such a result can be seen in the program adopted by A \& $\mathrm{P}$ after it was held in violation of the section. To avoid receipt of special allow-

61 Henry Broch \& Co. contended before the Commission that an actual savings in costs and expenses to them was attributable to the size of Smucker's order. The willingness to take a smaller rate on a bigger transaction was justified, the broker claimed, because the return on such a deal was proportionally greater than from a number of small sales at a higher rate which required more time, effort, and expense. Record, p. 8.

62363 U.S. at 174. In an eariy case, the court concluded that the buyer intended to avoid the prohibition of section 2(c), but no case has indicated that such intention was a prerequisite to establishing a violation. Great Atl. \& Pac. Tea Co. v. FTC, 106 F.2d 667, 672 (3rd Cir. 1939).

6349 Stat. 1527 (1936), 15 U.S.C. $\$ 13(f)$ (1958).

64 Thomas Page Mill Co., 33 F.T.C. 1437 (1941).

65 "Buyer and seller alike have violated the statute if the dişcount has been subştituted for a brokerage payment." EDWARDS 101, 
ances, A \& $\mathrm{P}$ subsequently relied chiefly on direct buying through its field agents, negotiating primarily with suppliers who used salesmen instead of brokers. 66 The suggestion in Broch of requisite motive, economic pressure, and knowledge by the buyer to establish a violation, however, does appear consistent with the Court's over-all qualification of the section in terms of the "purpose" of the price reduction. ${ }^{67}$

The language and rationale of Broch, furthermore, bring into focus the suspect situation of a price concession to a direct buyer made by a seller who sells to others through brokers. The Commission, sustained by the Third Circuit in the $A \& P$ case, 68 had held such a price concession to a direct buyer violative of section 2(c), not section 2(a). ${ }^{69}$ In Union Malleable Mfg. Co.,70 for example, the Commission's complaint alleged that the seller granted Sears Roebuck an additional discount not allowed the buyers who purchased through brokers, the lower price reflecting "all or a portion of the commission or brokerage." 71 The orders in these cases were framed in such a way as to suggest that a seller's lower price to a direct purchaser must be presumed as a matter of law to represent forbidden allowances of fees to brokers paid in connection with sales to other customers. However, the Commission appears to have tempered its position when, in a case of this type, Main Fish Co.,72 the complaint was dismissed on the grounds that the price differences "were not shown to be arithmetically commensurate with the pattern of brokerage."73 Also suggesting less automatic application of section 2(c) was the

66 See EdWards 109.

${ }^{67}$ Such an approach would avoid the anomalous situation in Thomas Page Mill Co., 33 F.T.C. 1437 (1941), but clearly at the expense of the absolute thrust of section 2(c).

68106 F.2d 667 (3rd Cir. 1939). Accord, Southgage Brokerage Co. v. FTC, 150 F.2d 607 (4th Cir. 1945).

${ }^{69}$ Cease-and-desist orders were issued against buyers in, e.g., Great Atl. \& Pac. Tea Co., 26 F.T.C. 486 (1938); General Grocer Co., 33 F.T.C. 377 (1941); R. C. Williams \& Co., 33 F.T.C. 1182 (1941); and against sellers in, e.g., Union Malleable Mfg. Co., 52 F.T.C. 408 (1955); Ramsdell Packing Co., 32 F.T.C. 1187 (1941).

7052 F.T.C. 408 (1955).

${ }^{71}$ An illustration of the pricing practice was shown by comparing invoices given on the same day to Sears and a buyer using a broker. The invoice to Sears showed the product sold at $\$ 130$ less a discount of $62-5-5-5-5-5 \%$ or a net price of $\$ 38.22$, while the same iron fitting was sold to another buyer at a discount of $62-5-5-5-5 \%$, or a net of $\$ 40.23$. Id. at 410 .

Topco Associates, Inc., 51 F.T.C. 83 (1954), is representative of other methods used to conceal a lower net price reflecting brokerage. One such method was a "cost-plus" arrangement whereby the seller furnished the respondent with a break-down of costs of raw materials plus cost of manufacturing, cans, cartons and packaging, but excluding all sales expenses which included costs of brokerage. More devious was the deduction of a specific amount per hundredweight which was charged as "packaging mark-up" to buyers who used brokers. Id. at 86.

7253 F.T.C. 88 (1956).

${ }^{73} \mathrm{Id}$. at 97 . Since Main Fish Co. was dealing in a perishable commodity not comparable to canned goods, the case may be indicative only of the method of selling two different food 
proceeding in 1956 against a seller who had made concessions to large direct buyers while selling to others through brokers. Because of the excess of price spread over and above the cost of brokerage, the proceeding was brought under section 2(a) instead of section 2(c). 74

The Supreme Court in Broch apparently acquiesced in the Commission's change of heart by citing Main Fish Co. for the proposition that "whether such a reduction [in price] is tantamount to a discriminatory payment of brokerage depends on the circumstances of each case."75 By allowing the Commission to impose a reasonable standard in the direct selling area, an effective compromise may have been reached. Perhaps absolutely enforcing section 2(c) is not as responsible an approach as initially determining the validity of cost differentials under section 2(a). ${ }^{76}$ The anomaly, however, still remains. A manufacturer who sells exclusively through his own salesman may pass along to the direct buyer his chief saving in selling cost, the cost of the salesmen, 77 while the seller who uses brokers in some transactions is prohibited from passing on his savings in the cost of brokerage on some, but apparently not all, direct sales. 78

A related problem in the conflict between the proper use of sections 2(a) and 2(c) was raised in Robinson v. Stanley Home Prods., Inc., 79 where it was

products. Fluctuating prices, lack of price lists, and disparate merchandising practices in perishable goods suggest the difficulty of establishing a set brokerage pattern to prove a violation. Id. at 97.

74 Fruitvale Canning Co., No. 5989 (June 15, 1956). Discussed in Edwards 101 n.26.

75363 U.S. at 176.

76 Professor Oppenheim suggested in 1940: "The Commission could consider each case on its facts. It could weigh the selling and buying methods of the particular parties, the absence of secrecy in their price policies, the customs of the trade and the disparity, if any, in economic power and circumstances. The risks of evasion would be counteracted by the burden placed upon respondents in demonstrating the savings, as in any 2(a) proceedings." Oppenheim, Administration of the Brokerage Provision of the Robinson-Patman Act, 8 GEO. WASH. L. REV. 511,537 (1940).

77 It may now be necessary to distinguish between the integrated sales organization with salaried personnel and the seller who compensates his salesmen on a commission or salary plus commission basis. In Thomasville Chair Co., No. 7273 (Aug. 12, 1960), a manufacturer utilizing the latter method, allegedly paid a lower rate of commission to its \&les representatives on orders from buyers whose annual purchases exceeded a specified amount; these orders were billed at a lower price. The complaint against the seller under section 2(c) was dismissed on evidentiary grounds, but notice of appeal was filed Sept. 8, 1960. See 80 CoNG. REC. 9417 (1936) (remarks of Representative Utterback) where it was suggested that savings by the use of "traveling salesmen solicitation" and direct selling were "illustrative of the way in which the bill permits the translation of differences in costs into price differences as between the customers concerned."

78 In the direct buying situation, some confusion may have been unnecessarily fostered by the Court's dictum suggesting that evidence of "services rendered" by the buyer might make a difference. 363 U.S. at 173.

79272 F.2d 601 (1st Cir. 1959). Robinson was decided after the Seventh Circuit opinion in Broch but prior to the Supreme Court decision. Both the majority and the dissent cite the case, 363 U.S. at $176 \mathrm{n} .18,187 \mathrm{n.12}$, 
held that section 2(c) was not violated by a seller who eliminated the services of a broker entirely, converted to direct selling, and thereafter reduced his prices. The sales agent of a Pennsylvania manufacturing firm had previously procured two orders from the buyer, when the buyer sought to deal directly with the manufacturer. When the agent was subsequently discharged and the manufacturer agreed to deal with the buyer, the agent brought a treble damage suit, claiming that the commission he would have been paid as agent was in fact given the buyer in the form of a price reduction in violation of section 2(c). The district court held that the broker had not alleged a cause of action, further asserting that the reduction or elimination of brokerage payable by the seller to its agent was not forbidden, citing the Broch opinion of the Seventh Circuit. 80 The First Circuit affirmed, but on the grounds that the reduction in price was not shown to be in lieu of a commission. ${ }^{81}$ The "purpose" of the reduction was held controlling, and the illegitimacy of that purpose was not shown.

In Broch, the Court, by way of a footnote, asserted that Robinson was correctly decided. ${ }^{82}$ But the Robinson rationale is framed in terms of the purpose for a reduction in price. ${ }^{83}$ How then are we to determine when a seller may legitimately eliminate a salesman and pass on the savings to a buyer without violating section 2(c)? The court assumed that no other brokers were employed. It has been suggested that there would have been no difficulty in finding a discount in lieu of a commission had the agent been relieved of only one account, and had he and other agents continued selling to others, with the subsequent reduction in price. 84 In a situation with only one agent, however, the buyer might specifically ask for a discount in terms of the eliminated broker's fee. Then the purpose for the reduction would be to receive a discount in lieu of brokerage. The Robinson court stated that the fact that there was discrimination does not mean the favored customer received brokerage. But to show "illegitimacy" of purpose, it would seem that whether there was discrimination would be an important factor in showing the purpose of the reduction. Since section 2 (c) necessitates no showing of discrimination be-

80178 F. Supp. 230 (D. Mass. 1959).

81 Robinson v. Stanley Home Prods., Inc., 174 F. Supp. 414 (D.N.J. 1959), where the same parties were concerned held that section 2(c) was not meant to include agents of the seller. The First Circuit preferred not to discuss the New Jersey case for they had "some doubts" about the lower court decision in Broch, upon which the New Jersey District Court relied. 272 F.2d at 602 n.1.

82363 U.S. at 176 n.18.

83 "While a reduction in price to the buyer could fall within ... [an "allowance or discount in lieu thereof"], obviously not every one would do so. The question must be, what was the purpose of, or the reason for, the reduction?" 272 F.2d at 603.

841 Boston College IND. \& COM. L. REv. 274, 276 (1960) (dealing with the Robinson case). 
tween customers to establish a violation, the fusion or confusion of 2(a) and 2 (c) is once again apparent. 85

\section{CONCLUSION}

The underlying inconsistency and conflict between sections 2(c) and 2(a) is an effect of the inclusion in 2(c) of the phrase "any allowance or discount in lieu thereof." It was to be anticipated that the prohibition would extend to an uncertain degree to price reductions that were associated with, or sequels to, the prohibited payments.86 Thus price concessions and payments that might otherwise be subject to 2 (a) or to the advertising allowances prohibited in 2(d) are instead subject to the brokerage provision if they are found to be in lieu of brokerage. Confronted by the harsh, absolute prohibition, the Supreme Court in Broch compromised.

The "compromise" is framed in terms of the intention or purpose behind a reduction or elimination of brokerage. Although price discrimination is not necessarily an element of the offense, it now appears essential in directdealing and reduced-commission cases to show that the seller sold to other customers and to indicate the prices charged, in order to prove that the discount was in lieu of brokerage. 87 Furthermore, although cost differences do not make lawful a discount in lieu of brokerage, evidence that such differences exist may now be relevant. 88

Despite the Court's disavowal, 89 perhaps section 2(c) is now at least partially consistent with section 2(a). As a result, for the FTC to establish its

85 The Court in Broch felt that Congress, by deleting the phrase "other than brokerage" from the cost proviso in section 2(a), showed an intention that "Iegitimacy" of brokerage be governed entirely by 2 (c). 363 U.S. at $171 \mathrm{n} .8$. Besides its relevance to the above discussion in the text, that construction of congressional intent may have rendered moot the contention that in a proceeding under 2(a), a differential price can reflect savings in costs including brokerage. For a conflicting opinion on this issue compare Rowe, supra note 31, at 132 with Oppenheim, supra note 76 , at 535.

86 EDWARDS 54.

87 The suggestion was first made regarding the direct-dealing cases by AUSTIN, PRICE Discrimination aNd Related Problems UNDER the Robinson-Patman Act 107 (rev, ed. 1953).

88 At an earlier stage in Thomasville Chair Co., No. 7273 (Aug. 12. 1960) (See note 77 supra), an opinion of the Commission established that, while cost justification was not a defense to a section 2(c) charge, cost data was admissible evidence to demonstrate that a price reduction and a contemporaneous brokerage reduction were unrelated. Order Denying Respondent's Interlocutory Appeal, No. 7273 (May 11, 1959). The practical effect of that opinion would appear to be the same as if the cost defense were explicitly allowed. Paradoxically, although the admission of cost data in a 2(c) hearing would soften the criticized automatic application of the section, the language of Broch would presumably reverse such a practice. 363 U.S. at 176.

89 "Nor does this 'fuse' provisions of $\S 2$ (a), which permits the defense of cost justification, with those of $\$ 2$ (c) which does not." 363 U.S. at 176. 
charges under a 2(c) complaint, some uniformity of price differential should be established at a level approximating the pattern of brokerage involved. 90 If the Commission chooses wisely, the per se thrust of the brokerage provision will not be rendered nugatory. That Broch has provided the occasion for re-examination of section 2(c) is clear. That Broch has forestalled unnecessary litigation in the future is not so evident.

${ }^{90}$ See the Commission's attitude as expressed in Main Fish Co., 53 F.T.C. 88, 93 (1956).

\section{CAPITAL GAINS TAXATION OF A LEGAL LIFE TENANT WITH A LIMITED POWER TO CONSUME CORPUS}

In United States v. De Bonchamps, 1 the Ninth Circuit Court of Appeals held that where one has a legal life estate with power to consume corpus when necessary for maintenance and support, he should be taxed on capital gains realized from the sale of any portion of the corpus as if he were fiduciary of a trust. ${ }^{2}$ The court expressly overruled its decision in United States $v$. Cooke $^{3}$ where it determined that the legal life tenant was not to be taxed on such gains at all, and in doing so, it chose to follow the course recently established by the Court of Claims in Weil v. United States. 4

\section{The Substantial OWNershIP Theory}

The government sought, unsuccessfully, in each of these three actions, to tax the life tenant in his individual capacity. In the Cooke case, the government's contention, though not entirely clear from the opinion, seems to have been that the taxpayer was given sufficient power in the testator's will to control disposition of the corpus that she ought to be considered owner thereof. ${ }^{5}$ As owner, she would clearly be taxable on capital gains realized on

1278 F.2d 127 (9th Cir. 1960).

2 Under the provisions of INT. Rev. CODE OF 1954, § 641 .

3228 F.2d 667 (9th Cir. 1955).

4180 F. Supp. 407 (Ct. Cl. 1960), cert. denied, 364 U.S. 822 (1960). There is evidence that Congress favors the rule expressed in the Weil and De Bonchamps cases. The Senate was, at the time of the De Bonchamps case, reviewing the provisions of a bill, H.R. 9662. "Under the bill, a trust will be deemed to exist for the calendar year with respect to that gain, and the person holding the legal life estate or other terminable interest will be deemed to be a fiduciary of the trust and will be required to report the gain and pay the appropriate tax." Hearings on H.R. 9662 Before the Senate Committee on Finance, 86th Cong., 2d Sess. 37 (1960). The dissent in De Bonchamps contended that the fact that the bill was up for passage implied that congressional intent could not be gleaned from the Code as it then stood, and that to read into the Code such intent would be to usurp the legislative function.

5 This, essentially, was the government's position in Ella E. Russell, 45 B.T.A. 397 (1941). In that case, the taxpayer was life beneficiary of a trust with power to order the trustees to dispose of principal when necessary for her maintenance and support. The Board held that all income from the corpus, including profits derived by sales thereof, were taxable to the beneficiary in her individual capacity by reason of her right to complete use and enjoyment. 